\title{
Using cell cycle analysis to estimate in situ growth rate of the dinoflagellate Dinophysis acuminata: drawbacks of the DNA quantification method
}

\author{
Lars-Åke Gisselson*, Edna Granéli, Per Carlsson \\ Department of Marine Sciences, University of Kalmar, Box 905, S-39 129 Kalmar, Sweden
}

\begin{abstract}
In an attempt to use cell cycle analysis to estimate in situ gross growth rate of the dinoflagellate Dinophysis acuminata, epifluorescence microscopy in combination with an image analysis system was used to measure the relative DNA content of DAPI stained $D$. acuminata nuclei. To be able to estimate growth rate with this method, the time it takes for a cell to synthesise a second DNA copy and complete mitosis (the duration of the terminal event in the cell cycle) must be known or measurable. The duration of the terminal event is normally estimated graphically from diurnal variations in the phase fraction curves. No diurnal variation in the phase fractions was detected in this study, and consequently no reliable estimate of the duration of the terminal event could be obtained. The main drawback was the difficulty in delineating the $S$ phase in DNA histograms based on only a few hundred cells. No clear $\mathrm{S}$ phase maximum could be obtained during our $48 \mathrm{~h}$ study. The presence of doublenucleated cells and a constantly high percentage (23 to $43 \%$ ) of cells with double genomes (G2 $+M$ phase cells) suggests, under the assumption that no cells can arrest in the G2 or M phase, that the population was actively dividing, but not clearly in phase with a diurnal cycle. Chang \& Carpenter (1991) previously estimated the duration of the terminal event (the duration of the $S+G 2+M$ phases) in this species to be 11 to $13 \mathrm{~h}$. A $12 \mathrm{~h}$ duration of the terminal event in this study would yield specific growth rates of 0.69 to $0.75 \mathrm{~d}^{-1}$ We conclude that the number of cells that can be measured using epifluorescence microscopy (a few hundred per sample) is too low to allow detection of a low degree of synchronisation, especially with regard to the $S$ phase. Estimations of in situ growth rate of poorly synchronised populations of phytoplankton using the cell cycle technique will require DNA measurements on several thousand cells per sample, e.g. using flow cytometry or automated image cytometry.
\end{abstract}

KEY WORDS: Dinophysis acuminata In situ growth rate $\cdot$ DNA $\cdot$ Cell cycle $\cdot$ Image analysis

\section{INTRODUCTION}

The dinoflagellate genus Dinophysis includes several toxin-producing species; these toxines are known to cause DSP (diarrhetic shellfish poisoning) when accumulated in bivalves (e.g. Yasumoto et al. 1980, Hallegraeff 1993, Subba Rao et al. 1993). Due to the economic importance of these dinoflagellates much interest has been focused on the autecology of Dinophysis in order to better understand the regulation of bloom formation and toxin production.

Studies on the physiology and growth characteristics of Dinophysis species are still scarce due to the impos-

•E-mail: lars-ake.gisselson@ng.hik.se sibility of maintaining them in culture (e.g. Sampayo 1993. Maestrini et al. 1995, Subba Rao 1995). In order to get information on the ecophysiology of Dinophysis species, it is thus necessary to study their growth characteristics in situ, among all the co-occurring species in the phytoplankton community.

Different approaches have been used to monitor dinoflagellate growth in situ, including cell counting (Delmas et al. 1992), inorganic ${ }^{14} \mathrm{C}$ incubations followed by single cell isolation and scintillation counting (Granéli et al. 1997), and cell cycle analysis (Swift \& Durbin 1972, Chang \& Carpenter 1991, Carpenter et al. 1995). Use of in situ changes in cell numbers to estimate growth rate is problematic, since concurrent losses due to grazing, sinking and lysis will be in- 
cluded, yielding, at best, a net growth rate of the population that gives little information about cell growth. Incubation of the natural communities with ${ }^{14} \mathrm{C}$ bicarbonate, followed by single cell isolation of the species of interest can provide an estimate of gross growth rate, and thus of the physiological status. However, this technique requires incubation and thereby does not avoid the problems with containment, bottle effects etc. There are also uncertainties due to isotope dilution, excretion of photosynthates and heterotrophic activity in the samples. The application of cell cycle analysis for measuring DNA replication rate is thus especially attractive with regard to Dinophysis species, since it avoids containment effects and gives a measurement of in situ division rate which is potentially unaffected by grazing and other losses.

The cell cycle in eukaryotic cells is generally described as consisting of 4 phases: G1, S, G2 and M phase. $S$ being the DNA synthesis phase, G1 and G2 phases representing cells with 1 and 2 copies of the genome respectively and the $\mathrm{M}$ phase consisting of cells going through mitosis. The use of the cell cycle method relies on the assumption that all cells that leave the G1 phase will synthesise DNA at a constant rate and complete mitosis within a constant time, i.e. no cells will arrest in the division cycle during S, G2 or M phases (e.g. Carpenter \& Chang 1988). This period is referred to as the terminal event, in this study chosen to be the duration of the $S, G 2$, and M phases. G1 is regarded as an untimed 'gap' in the cell cycle. Phytoplankton cells are believed to be restrained in G1 phase until they have accumulated enough resources to complete mitosis. Using phytoplankton cultures, it has been shown that nitrogen deficiency or the absence of light results in accumulation of cells in G1 phase (Vaulot 1995).

A problem with the cell cycle approach, when working with cell populations in situ, is that it requires some degree of diurnal synchronisation of cell division to allow an estimation of the duration of the terminal event for the species of interest under the prevailing conditions. The duration of the terminal event, in this case the duration of the $S, G 2$, and $M$ phases, is determined graphically from the time series of phase fractions (percentage of the cell population in each of the G1, S and G2 + M phases plotted versus time for $>24 \mathrm{~h}$ ) for each population. Diel synchronisation of cell division is common in phytoplankton (Swift \& Durbin 1972, Weiler \& Chisholm 1976, Rivkin et al. 1984, Chang \& Carpenter 1985 etc.) and the cell cycle approach has previously been applied to estimate in situ growth rates of a synchronised population of Dinophysis acuminata in Long Island Sound (Chang \& Carpenter 1991).

Some Dinophysis species are known to be heterotrophic (Hallegraeff \& Lucas 1988, Hansen 1991), and there is evidence that the phototrophic Dinophysis acuminata and $D$. norvegica are mixotrophic, based on the observation of food vacuoles inside the cells (Jacobson \& Andersen 1994). Heterotrophic growth in the dark may reduce the degree of diurnal synchronisation of the cell cycle, or even allow asynchronous division during all stages of the diel cycle. This mode of growth has been suggested to explain lack of synchrony in a population of Dinophysis norvegica located in the thermocline of the Baltic Sea (Carpenter et al. 1995). Cell cycle analysis on a poorly synchronised phytoplankton population requires a very high resolution in the DNA histograms to allow unambiguous delineation of the phase fractions, especially the $\mathrm{S}$ phase fraction, i.e. a large number of cells must be measured in each sample to reduce statistical variability.

If cell division is totally unsynchronised, current methods for calculation of growth rate from time series of DNA distributions are difficult or even impossible, since durations of cell cycle phases cannot be determined from the phase fraction curves. Growth rate of asynchronous populations can only be determined if the duration of the terminal event, $T_{d}$, is known, e.g from culture experiments. This has not been achieved for Dinophysis species; moreover, $T_{d}$ for a single species has been shown to vary with growth conditions, and between sub-populations within 1 species (e.g. Videau \& Partensky 1990). The purpose of this study was to use the cell cycle approach to estimate growth rate of a Dinophysis acuminata population growing in situ.

\section{MATERIALS AND METHODS}

The study was performed with Dinophysis acuminata cells obtained from the Gullmar Fjord, SE Skagerrak, Sweden. From the pier of Kristineberg Marine Research Station at Fiskebäckskil (58 $\left.15^{\prime} \mathrm{N}, 11^{\circ} 27^{\prime} \mathrm{E}\right)$, water samples were taken with 2 submersible pumps from 3 to 5 October 1995. Depth at the sampling site was $6 \mathrm{~m}$, and tidal amplitude in the area is 20 to $30 \mathrm{~cm}$ (Flg. 1). Pump intakes were deployed at 0.5 and $5 \mathrm{~m}$ depth. Samples were taken every $2 \mathrm{~h}$ over a $48 \mathrm{~h}$ period, from $22: 00 \mathrm{~h}$ on 3 October to $22: 00 \mathrm{~h}$ on 5 October. Sunrise was at 06:21 $\mathrm{h}$ and sunset at 17:40 h local time on 3 October. Insolation (PAR), tidal amplitude, wind speed, water temperature and salinity were obtained from a database of the Kristineberg Marine Research Station, where these parameters are measured continously and stored on computer. Temperature and salinity were also measured manually at every $1 / 2 \mathrm{~m}$ depth down to the bottom $(6 \mathrm{~m})$ at $12 \mathrm{~h}$ intervals. Inorganic nutrients were analysed, at $12 \mathrm{~h}$ intervals, according to Valderrama (1995). Plankton 


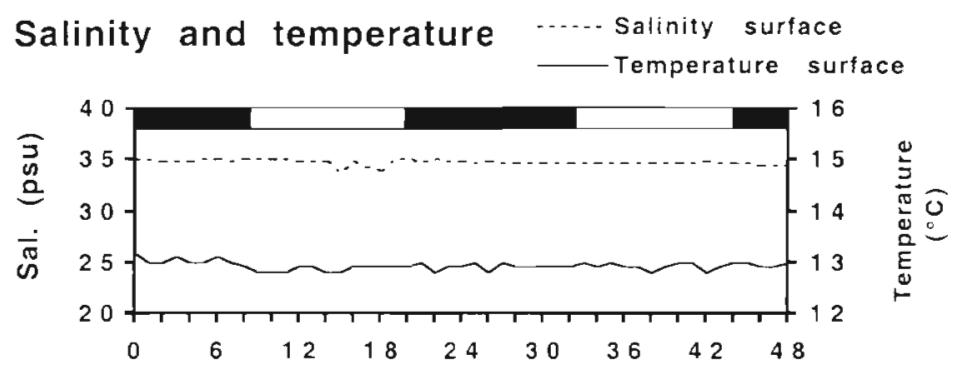

Tidal fluctuation
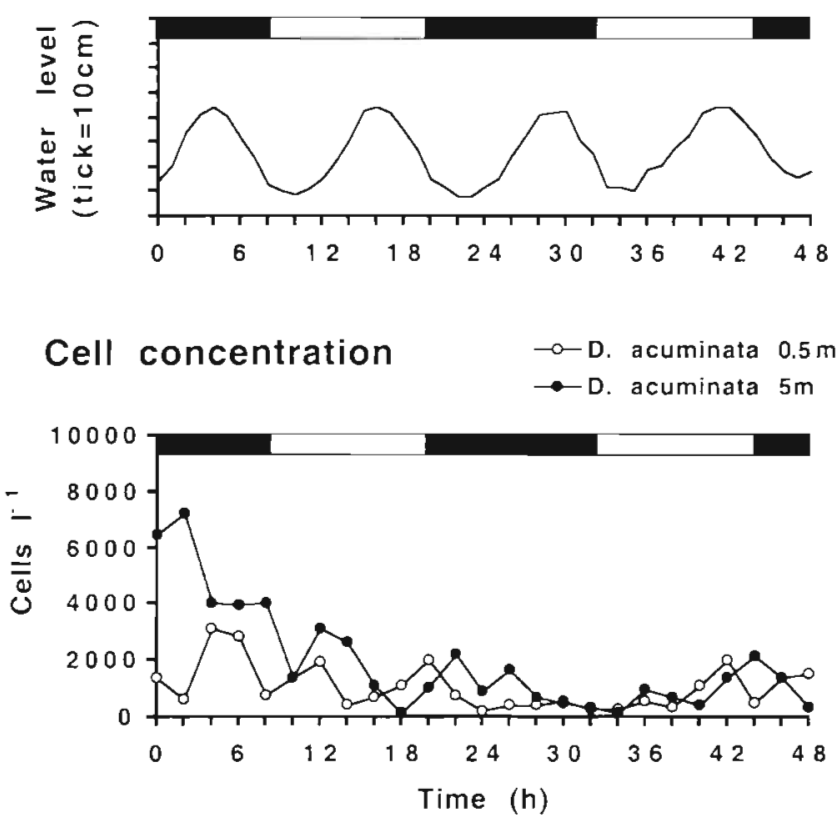

Fig. 1. Salinity (surface), temperature (surface), tidal fluctuation $(1$ scale mark $=10 \mathrm{~cm})$, and abundance of Dinophysis acuminata at the surface $(0.5 \mathrm{~m})$ and at $5 \mathrm{~m}$ depth, during the studied $48 \mathrm{~h}$ period. Time 0 is 22:00 h on 3 October. Dark and light periods are shown on top of the diagrams

samples were taken and preserved with acid Lugol's solution at all sampling events. Cells were counted according to Utermöhl (1958) using $50 \mathrm{ml}$ counting chambers and a Nikon Diaphot inverted microscope.

To obtain a large number of Dinophysis acuminata cells, and to remove to the extent possible, other particles, $200 \mathrm{l}$ of water was poured through 60,45 and $20 \mu \mathrm{m}$ mesh size nylon nets in series, with the lower nets hanging down into a container with overflow outlets to keep the cells submersed (Maestrini et al. 1995). A concentrated suspension of cells was gently collected from the top of the $20 \mu \mathrm{m}$ mesh size net with a jar, thus yielding a concentration of 20 to $45 \mu \mathrm{m}$ sized cells. This suspension was further concentrated on a small $20 \mu \mathrm{m}$ mesh net until the volume was reduced to $12 \mathrm{ml}$. The cell concentrate was preserved with formaldehyde to a final concentration of $4 \%$ and refriger- ated for $2 \mathrm{~h}$. The concentrate was then centrifuged at $1500 \times g$, the supernatant aspirated, and $12 \mathrm{ml}$ of $-20^{\circ} \mathrm{C}$ methanol added to extract pigments. The samples were stored in the methanol at $-20^{\circ} \mathrm{C}$ until staining and cell cycle analysis could be performed.

For DNA measurements, a $2 \mathrm{ml}$ subsample was drawn from each cell concentrate and left to settle in $2 \mathrm{ml}$ Eppendorf tubes for ca $1 \mathrm{~h}$. After settlement, the methanol was aspirated and $2 \mathrm{ml}$ of distilled water added. This washing was repeated once, allowing the cells to settle in between, and finally DAPI (4'6-diamidino-2phenylindole) was added to give a final concentration of 1.0 or $0.5 \mu \mathrm{g} \mathrm{ml}^{-1}$, depending on the quantity of material in the sample. Different stain concentrations had to be used, since different amounts of material (cells, copepod faecal pellets and debris) in the samples affected the quality of the staining. DAPI concentration was optimised (by trial and error) to stain the Dinophysis acuminata nuclei with minimal staining of the cytoplasm and theca. The cells were then left to stain for $2 \mathrm{~h}$ with frequent mixing of the sample. After the cells had settled, the staining solution above the pellet was aspirated away, and the pellet was washed twice with distilled water. After a final settling, water was aspirated leaving about $100 \mu \mathrm{l}$ of water with the cell pellet. Next, $20 \mu \mathrm{l}$ of this concentrated cell suspension was withdrawn with an automatic pipette and mounted with a cover glass on a microscope slide. The coverglass was sealed with nailpolish to prevent the sample from drying. The relative DNA content in the nuclei of the Dinophysis acuminata cells was measured using an Olympus BX 50 epifluorescence microscope with a UV excitation filter at a magnification of $200 \times$. A CCD camera was used to capture 40 to 70 images (camera head and image processor Optronics VI-470, Optronics Engineering, Goleta, CA, USA), which were digitalised (ImageGrabber 24 1.2, Neotech Ltd, Eastleigh, Hampshire, UK) and stored on computer. Images were analysed with the IP Lab Spectrum image analysis program (Signal Analytics Corporation, Vienna, CA, USA). To minimise noise from unspecific staining of the cytoplasm and theca, a semi-automatic program routine was developed to delineate the nuclei of the desired cells, and only fluorescence from within the area of the nucleus was quantified. Nuclei were selected manually by recognition of the desired cells. Data for each nucleus, i.e. area, mean pixel brightness and sum of pixel brightness in grayscale, was stored in text file format. A total of 400 to 500 nuclei per sample were measured. The sum of pixel brightness in each 


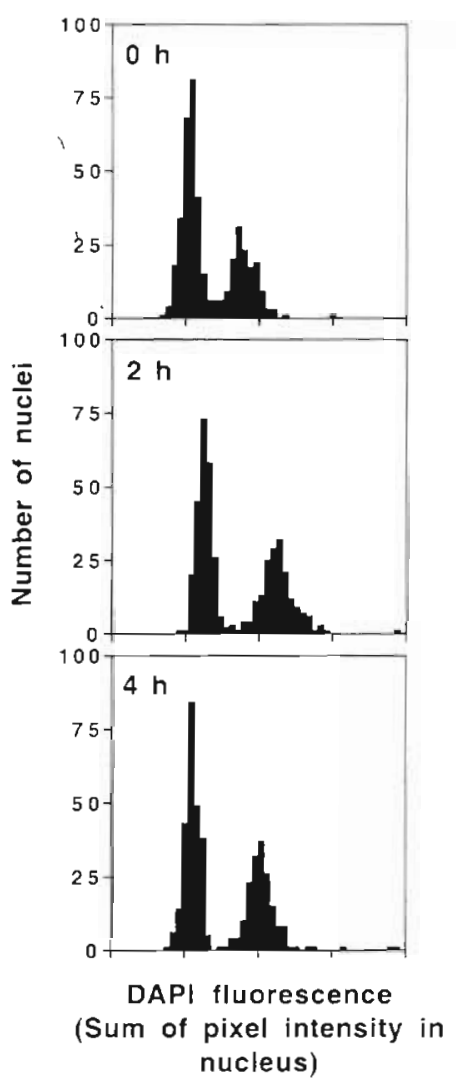

Fig. 2. Dinophysis acuminata. Representative DNA histograms obtained from image analysis of 400 to 500 cells. Relative DNA content is estimated as the amount of DAPI fluorescence (sum of pixel intensity) within the nuclei of the dinoflagellate cells. Shown histograms are the first 3 samples from the surface

nucleus was used as measurement of the relative DNA. content. Histograms of relative DNA content (representative histograms shown in Fig. 2) for each sample were created in Microsoft Excel, where the Solver function was used to analyze the histograms by fitting normal distributions to the $G 1$ and $G 2+M$ peaks. The position of the G1 peak varies slightly between samples due to differences in staining intensity; however, the distributions were fitted to the peaks independently of the absolute position of the G1 peak. A rectangular distribution was fitted between the centres of the 2 normal distributions to estimate the $S$ phase fraction, since there was no identifiable peak occurring in this range of the histograms. The 3 distributions were fitted simultaneously. In histograms with a small $\mathrm{S}$ phase, as was the case in our time series, a rectangular distribution would give a fair approximation of the $\mathrm{S}$ phase distribution (Baisch et al. 1982).

Using the sum of $S$ and $G 2+M$ phase fractions, the daily mean specific growth rate $\mu_{S}+r_{2} M$ was calculated using the equation

$$
\mu_{\mathrm{S}+\mathrm{G} 2 \mathrm{M}}=\frac{1}{\left(\mathrm{~T}_{\mathrm{S}}+\mathrm{T}_{\mathrm{G} 2 \mathrm{M}}\right) \mathrm{n}} \sum_{j=1}^{\mathrm{n}} \ln \left[1+f_{\mathrm{S}}\left(t_{i}\right)+f_{\mathrm{G} 2 \mathrm{M}}\left(t_{i}\right)\right]
$$

(Carpenter \& Chang 1988), where $\mu_{S+G 2 M}$ is the daily mean specific growth rate. $T_{S}+T_{G 2 M}$ is the duration of the terminal event estimated graphically from the time lag between an $\mathrm{S}$ phase fraction maximum and the following maximum in $\mathrm{G} 2+\mathrm{M}$ phase, multiplying this time by 2 (Carpenter \& Chang 1988). $f_{\mathrm{S}}\left(t_{i}\right)$ and $f_{\mathrm{G} M \mathrm{M}}\left(t_{1}\right)$ are the phase fractions of the $\mathrm{S}$ and $\mathrm{G} 2+\mathrm{M}$ phases respectively at each sampling occasion, $t_{i}$. $n$ is the number of samples in the time series used for the calculation.

\section{RESULTS}

The water temperature remained constant, around $13^{\circ} \mathrm{C}$ from the surface to the bottom, during the 2 sampling days. Surface salinity varied between 32 and $35 \%$ (Fig. 1), being 2 to $3 \%$ higher at $5 \mathrm{~m}$ depth. The light intensity, measured as photosynthetically active radiation (PAR) in air on the roof of the laboratory, was low during the sampling period due to cloud cover $\left(<200 \mu \mathrm{E} \mathrm{s}^{-1} \mathrm{~m}^{-2}\right)$. The preceding days had PAR levels reaching $800 \mu \mathrm{E} \mathrm{s} \mathrm{m}^{-2}$ (Fig. 3). Wind speed was moderate during the experimental period: 3 to $7 \mathrm{~m} \mathrm{~s}^{-1}$. Wind speeds of up to $11 \mathrm{~m} \mathrm{~s}^{-1}$ were measured $2 \mathrm{~d}$ before the start of the experiment. The phosphate concentration was stable at 0.20 to $0.29 \mu \mathrm{M}$, and the concentration of nitrate ranged from 0.57 to $1.00 \mu \mathrm{m}$ over the $2 \mathrm{~d}$ period. Ammonium concentrations ranged from 0.15 to $1.78 \mu \mathrm{M}$, with the maximum concentration obtained at the surface at $36 \mathrm{~h}$. Dinophysis acuminata cell numbers in the surface water oscillated between

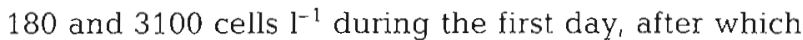

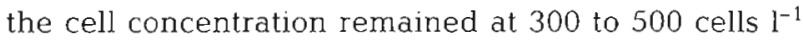
over the following night (Fig. 1). In the $5 \mathrm{~m}$ depth sam-

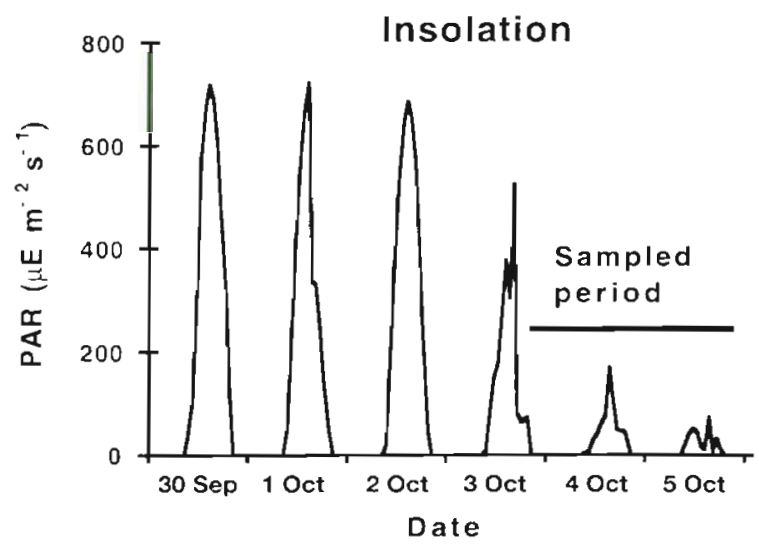

Fig. 3. Insolation during the study ( 3 to 5 October) and the preceding days measured as photosynthetically active radiation (PAR) in the air. The study was conducted from $22: 00 \mathrm{~h}$ on 3 October to $22: 00 \mathrm{~h}$ on 5 October. Insolation during the sample period was reduced due to cloud cover 


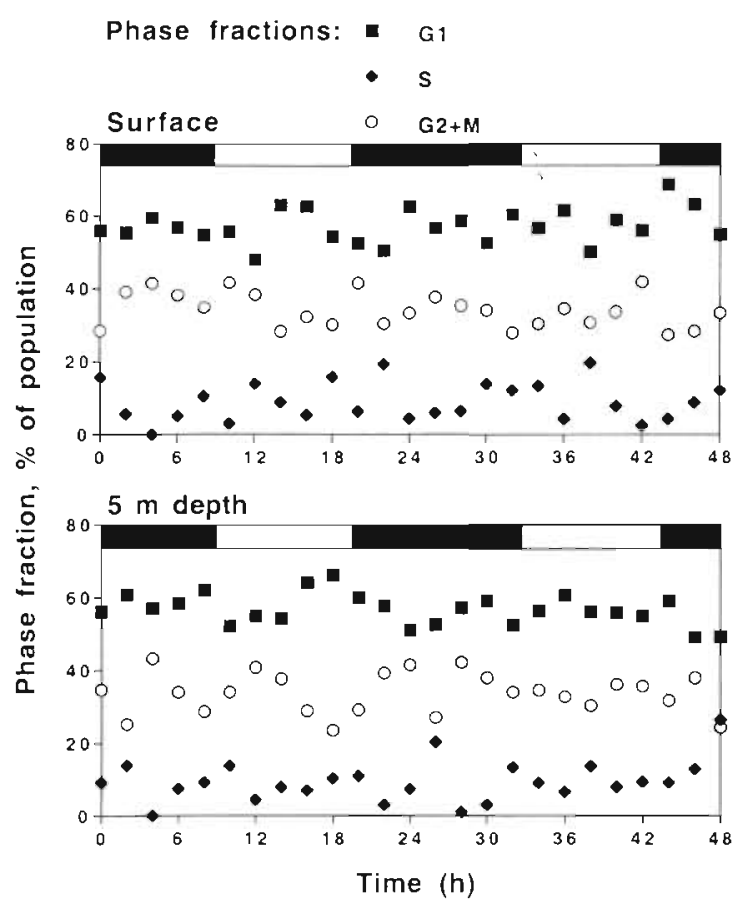

Fig. 4. Phase fractions in \% of the total number of Dinophysis acuminata cells in each sample. No attempt was made to fit curves to the data points, since only sporadic variations are observed and no diurnal trend can be detected. Time 0 is 22:00 h on 3 October. Light and dark periods are shown on top of the diagrams

ples, cell concentrations ranged from 140 to 7200 cells $\mathrm{I}^{-1}$, with a strong decrease during the first $18 \mathrm{~h}$. $D$. acuminata were more abundant at $5 \mathrm{~m}$ depth than in the surface water in 18 out of 25 samples.

The phase fraction curves did not exhibit any clear diurnal cycle, but rather several sporadic events (Fig. 4). Consequently no attempt was made to fit polynomial functions to the data. The $\mathrm{G} 2+\mathrm{M}$ phase fraction in the Dinophysis acuminata population in the surface water ranged between 27 and $42 \%$, with maxima at $4,10,20$ and $42 \mathrm{~h}$. At $5 \mathrm{~m}$ depth, the $\mathrm{G} 2+\mathrm{M}$ phase fraction ranged from 23 to $43 \%$ of the population with maxima at $4,12,24$ and $28 \mathrm{~h}$. The $\mathrm{S}$ phase fraction in the surface water varied between 0 and $20 \%$ of the population, and between 0 and $27 \%$ of the population at $5 \mathrm{~m}$ depth. In the majority of the samples at both depths, the fraction of cells in S phase was below $10 \%$. The coefficients of variation for the G1 and $G 2+M$ peaks were generally between 7 and $8 \%$ and in some histograms as high as $11 \%$.

Due to the lack of evident peaks in the $S$ and $G 2+M$ phase fraction curves, it was not possible to obtain a reliable graphical estimate of the duration of the terminal event $\left(T_{S}+T_{G 2 M}\right)$. Alternative growth rate estimates in relation to hypothetical values of $T_{S}+T_{G 2 M}$ are, however, proposed and further discussed (Table 1).
Table 1. Estimates of daily mean specific growth rate $(\mu)\left(\mathrm{d}^{-1}\right)$ obtained for Dinophysis acuminata using hypothetical durations of the terminal event $\left(T_{S}+T_{G i 2 M}\right)$. See 'Discussion'

\begin{tabular}{|ccccc|}
\hline $\mathrm{T}_{\mathrm{S}}+\mathrm{T}_{\mathrm{G} 2 \mathrm{M}}$ & $\begin{array}{c}0-24 \mathrm{~h} \\
\text { Surface }\end{array}$ & $\begin{array}{c}24-48 \mathrm{~h} \\
\text { Surface }\end{array}$ & $\begin{array}{c}0-24 \mathrm{~h} \\
5 \mathrm{~m}\end{array}$ & $\begin{array}{c}24-48 \mathrm{~h} \\
5 \mathrm{~m}\end{array}$ \\
\hline $8 \mathrm{~h}$ & 1.09 & 1.04 & 1.05 & 1.12 \\
$12 \mathrm{~h}$ & 0.73 & 0.69 & 0.70 & 0.75 \\
$16 \mathrm{~h}$ & 0.54 & 0.52 & 0.52 & 0.56 \\
$24 \mathrm{~h}$ & 0.36 & 0.35 & 0.35 & 0.37 \\
\hline
\end{tabular}

\section{DISCUSSION}

\section{Growth rate estimates}

The first part of Eq. (1), which contains the $S+G 2+M$ duration estimate, depends on accurate positioning of $\mathrm{S}$ and $\mathrm{G} 2+\mathrm{M}$ maxima in the phase fraction curves. This proved to be impossible in this study due to an inability to detect any synchronisation of the cell cycle. One major drawback to the method applied here, using microscopy to analyse small samples (a few hundred cells), is that the $\mathrm{S}$ phase estimate is subject to considerable uncertainty from the procedure of curve fitting to the histograms. This is a serious problem in poorly synchronised populations (Baisch et al. 1982, Chang \& Carpenter 1990, 1991). The S phase overlaps with both the G1 and G2 phases, and the shape of the $\mathrm{S}$ phase distribution is not known. Most methods used to date to estimate the $\mathrm{S}$ phase fraction from DNA histograms have been shown, by applying the methods to computer-simulated cell populations, to underestimate the true $S$ phase fraction (Baisch et al. 1982). We observed that cohorts of cells in our histograms were sometimes accumulated as shoulders on the G1 and $\mathrm{G} 2+\mathrm{M}$ peaks, but never between the peaks, indicating that the progression through the $S$ phase of the Dinophysis acuminata population we studied might have been very fast, and/or the DNA synthesis rate was not constant in the sampled cells.

Chang \& Carpenter (1991) estimated the duration of the $\mathrm{S}$ phase in a natural population of Dinophysis acuminata in Long Island Sound to be $2 \mathrm{~h}$. This duration corresponds to the sampling interval in our study. Moreover, they obtained a measurable $S$ phase fraction only during $4 \mathrm{~h}$. This would correspond to 2 samplings in our study. These authors also quantified the fraction of double-nucleated cells in each sample, but did not obtain a good peak of the $M$ fraction in the diurnal phase fraction curves, but rather isolated high values. We observed, but did not count, double-nucleated cells, but there were never more than a few in any sample, thus the $\mathrm{M}$ fraction never exceeded 1 to $2 \%$ of the population. Chang \& Carpenter (1991) concluded 
that their sampling interval of $1 \mathrm{~h}$ was too long to locate a maximum in the $M$ phase due to its short duration, and that quantification of mitotic cells thus did not improve the accuracy of the growth rate estimation.

The large proportion of cells in the $\mathrm{G} 2+\mathrm{M}$ phase $(23$ to $43 \%$ ), together with the presence of double-nucleated cells, suggests that Dinophysis acuminata in our study was actively dividing, but with a low degree of diurnal synchronization. The measured concentrations of phosphate, nitrate and ammonium also suggest that growth should not have been arrested due to nutrient limitation during the course of the experiment.

When Chang \& Carpenter (1991) used cell cycle analysis to estimate growth rate of a population of Dinophysis acuminata in Long Island Sound, their S phase estimates ranged from 0 to $50 \%$ with a clear diurnal cycle, compared to sporadic variation between 0 to $27 \%$ in our study. Their G2 $+M$ phase estimates varied between 0 and almost $80 \%$, also with a clear diurnal coupling, compared to sporadic variations between 23 and $43 \%$ in our study. We can only speculate about the reasons for this low degree of synchronisation in our study. It is possible that the sharp decrease in insolation during the sampling period compared to the preceding days caused synchronisation to break down, e.g that induced heterotrophic or mixotrophic growth due to decreasing insolation allowed continuous cell division, uncoupled from the light:dark cycle. Weiler \& Chisholm (1976) also found poor synchrony in a population of $D$. acuminata in Santa Monica Bay, California, which prevented the use of the mitotic index to estimate in situ growth rate

Chang \& Carpenter (1991) estimated $\mathrm{T}_{\mathrm{S}}+\mathrm{T}_{\mathrm{C} 2 \mathrm{M}}$ in Dinophysis acuminata in their Long Island Sound study to be between 11 and $13 \mathrm{~h}$, which yielded a growth rate $(\mu)$ of 0.54 to $0.67 \mathrm{~d}^{-1}$. In our study, a $\mathrm{T}_{\mathrm{S}}+$ $\mathrm{T}_{\mathrm{G} 2 \mathrm{M}}$ of $12 \mathrm{~h}$ yielded specific growth rates of 0.69 to $0.75 \mathrm{~d}^{-1}$ with the phase fractions obtained. Assuming a longer $T_{S}+T_{G 2 M}$ of $16 \mathrm{~h}$, yields specific growth rates of 0.52 to $0.56 \mathrm{~d}^{-1}$, and a $24 \mathrm{~h}$ duration of the terminal event would give a growth rate of 0.35 to $0.37 \mathrm{~d}^{-1}$ (Table 1). It might be argued that all these estimates are rather high for a larye dinoflagellate, and that the measurement of a large $\mathrm{G} 2+\mathrm{M}$ phase fraction, as in our study, is enough to detect growth in a potentially bloom forming population, regardless of the duration of the terminal event. This is under the assumption that no cells arrest in the cell cycle during the G2 or $M$ phases, and that the duration of the terminal event is not longer than 1 diurnal cycle.

Granéli et al. (1997) measured species-specific carbon uptake rates of 3 Dinophysis species in 1993 at the same location used in this experiment. They calculated growth rate using the measured short term carbon uptake and the estimated carbon content per cell. The maximum specific growth rates estimated in their study were $0.59 \pm 0.13 \mathrm{~d}^{-1}$ for $D$. acuminata, $0.63 \pm$ $0.15 \mathrm{~d}^{-1}$ for $D$. norvegica and $0.41 \pm 0.04 \mathrm{~d}^{-1}$ for $D$. acuta. The values for $D$. acuminata obtained by Granéli et al. (1997) are similar to the growth rates obtained in our experiment when a $T_{S}+T_{G 2 M}$ of $16 \mathrm{~h}$ was used in the calculations

\section{Fluctuations in cell abundance}

The temporal variations in the abundance of Dinophysis acuminata at the 2 depths sampled is not clearly correlated with either the light:dark cycle, the tidal fluctuations, or the cell cycle. The long term decrease in cell numbers could be due to accumulation of cells at an unsampled layer in the water column, lateral exchange of water, cell death, or grazing. We observed increasing amounts of debris and copepod faecal pellets (not quantified) during the sampling period, suggesting a high grazer activity.

\section{Non growth or unsynchronised growth. Are the model assumptions satisfied?}

The absence of a clear $S$ phase during our $48 \mathrm{~h}$ study, together with the constantly high percentage of cells in $G 2+M$ phase, raises questions about the assumptions connected with the cell cycle model. The second part of Eq (1) is based on the fractions of cells present in $\mathrm{G} 2+\mathrm{M}$ phase throughout the period. The use of this term relies on the assumption that cells released from G1 will proceed through the cell cycle at a constant rate until mitosis. This assumption might not always hold. Whiteley et al. (1993) have shown that cell cycle control points in the heterotrophic dinoflagellate Oxyrrhis marina (restriction points) are present in both $G 1$ and $G 2$ phases, i.e. the cells can arrest in both $\mathrm{G} 1$ and $\mathrm{G} 2$. The presence of nongrowing cells in the $\mathrm{G} 2+\mathrm{M}$ phases would lead to overestimation of growth rate with the method applied here. In phototrophs, the main restriction point is usually situated in G1, i.e. cells cannot leave G1 until they have accumulated enough nutrients to complete division. Thus nutrient limitation in phototrophs usually leads to accumulation of cells in G1 (e.g. Vaulot 1995, Parpais et al. 1996). Diatoms are an exception: silica limitation has been shown to lead to arrest in G2 phase, due to the need for Si to complete frustule synthesis at mitosis (Vaulot et al. 1987) P limitation has been shown to induce arrest in both $\mathrm{S}$ and G2 in phototrophic prokaryotes, possibly due to the lack of a $\mathrm{P}$ restriction point in $\mathrm{G} 1$ in these organisms (Parpais et al. 1996). 
The sexual life cycle of dinoflagellates could introduce similar problems into the interpretation of DNA histograms. Many dinoflagellates display different morphological forms. In our samples, we observed a few extremely small Dinophysis cells resembling $D$. acuminata in shape, but they were never included in the DNA histograms. Unfortunately these cells were too rare to allow a separate cell cycle analysis. Mackenzie (1992) argued that the 2 size classes of $D$. acuta and D. acuminata represented different gametes in a sexual life cycle, but that both cell forms had the capability of vegetative reproduction. Similar observations have been made on D. pavillardi (Giacobbe \& Gangemi 1997). In this species the authors observed diploid planozygotes, morphologically similar to haploid vegetative cells, that showed no sign of cell division. Berland et al. (1995) suggested that the smaller morphotype should not be considered solely as gametes, but that both life cycle stages were capable of both vegetative and sexual reproduction. Partensky \& Vaulot (1989) proposed that the two size forms of Gymnodinium cf. nagasakiense are not gametes, but rather display different growth strategies, the smaller form dividing faster under favourable conditions and the larger being more resistant. If, on the contrary, diploid sexual cells with DNA content equal to $G 2+M$ cells are present in the studied population, this could introduce bias into the calculations of growth rate. Further studies, including DNA measurements on different morphotypes, are needed to establish ploidy and growth capability of sexual cells in Dinophysis species.

\section{Improvements of the approach}

The accuracy of phase fraction measurements using DNA quantification can be improved by increasing the number of cells measured in each sample. In poorly synchronised populations, it is necessary to detect small changes in phase fractions over the diurnal cycle. This will require measurement of a larger number of cells in each sample to reduce statistical variability. To measure several thousand cells per sample requires flow cytometry that could allow detection of a low degree of synchrony and thus give an accurate estimate of $T_{S}+T_{G 2 M}$. However, we have tried flow cytometry with the same sample set, but have so far failed to separate Dinophysis acuminata cells in $\mathrm{G} 2+\mathrm{M}$ phase from G1 phase cells of Prorocentrum micans, a species that was also abundant in the samples. Flow cytometry in combination with species-specific immunostaining (e.g. Vrieling et al. 1993) might be a way to solve this problem when working with natural populations. It is possible that analysis of a larger number of cells, e.g. using flow cytometry, would have allowed detection of a low degree of synchrony, and thus given an accurate $T_{S}+T_{G i m}$ estimate in our study.

The accuracy of phase fraction estimations could also be improved by using cell cycle markers that are active in the cells only during a specific part of the cell cycle, like proliferating cell nuclear antigen (PCNA) (Lin et al. 1994, 1995, Lin \& Carpenter 1995). These markers can be visualised by immunostaining and used instead of DNA quantification to measure progression through the cell cycle of a population. The application of cell cycle markers specific for active DNA replication would also eliminate the possible effect of growth arrested cells in the G2 or M phase. Moreover, since the cell cycle phase fraction is identified from the presence or non-presence of a marker protein, no quantification or deconvolving procedure is necessary. This means that the analysis can be performed with high precision on a relatively small number of cells using epifluorescence microscopy. This technique does not, however, eliminate the need for partial synchronisation of cell division in the studied population (e.g. Lin et al. 1997).

Acknowledgements. This work was supported by funds from the Swedish Natural Science Research Council (NFR) to E.G. Financial contributions to microscope and video equipment were provided by the Crafoord foundation and the Carl Trygger foundation. We are grateful to Prof. Miles Furnas, Australian Institute of Marine Science, Townsville, Australia, and 4 anonymous referees for constructive suggestions on the manuscript. We also thank Christer Nylander, Dept. of Marine Ecology, University of Lund, Sweden, for curve-fitting to the DNA histograms.

\section{LITERATURE CITED}

Baisch H, Beck HP, Christensen IJ, Hartmann NR, Fried J, Dean PN, Gray JW, Jett JH, Johnston DA, White RA Nicolini C, Zeitz S, Watson JV (1982) A comparison of mathematical methods for the analysis of DNA histograms obtained by flow cytometry. Cell Tissue Kinetics 15 $235-249$

Berland BR, Maestrini SY, Grzebyk D (1995) Observations on possible life cycle stages of the dinoflagellates Dinophysis cf. acuminata, Dinophysis acuta and Dinophysis pavillardi. Aquat Microb Ecol 9:183-189

Carpenter EJ, Chang J (1988) Species-specific phytoplankton growth rates via diel DNA synthesis cycles. I. Concept of the method. Mar Ecol Prog Ser 43:105-111

Carpenter EJ, Janson S, Boje R, Pollehne F, Chang J (1995) The dinoflagellate Dinophysis norvegica: biological and ecological observations in the Baltic Sea. Eur J Phycol 30: $1-9$

Chang J, Carpenter EJ (1985) Blooms of the dinoflagellate Gyrodinium aureolum in a Long Island estuary: box model analysis of bloom maintenance. Mar Biol 89:83-93

Chang J, Carpenter EJ (1990) Species-specific phytoplankton growth rates via diel DNA synthesis cycles. IV. Evaluation of the magnitude of error with computer-simulated cell populations. Mar Ecol Prog Ser 65:293-304 
Chang J, Carpenter EJ (1991) Species-specific phytoplankton growth rates via diel DNA synthesis cycles. V. Application to natural populations in Long Island Sound. Mar Ecol Prog Ser 78:115-122

Delmas D, Herbland A, Maestrini SY (1992) Environmental conditions which lead to increase in cell density of the toxic dinoflagellates Dinophysis spp. in nutrient-rich and nutrient-poor waters of the French Atlantic coast. Mar Ecol Prog Ser 89:53-61

Giacobbe MG, Gangemi E (1997) Vegetative and sexual aspects of Dinophysis pavillardi (dinophyceae). J Phycol 33:73-80

Granéli E, Anderson DM, Carlsson P, Maestrini SY (1997) Light and dark carbon uptake by Dinophysis species in comparison to other photosynthetic and heterotrophic dinoflagellates. Aquat Microb Ecol 13:177-186

Hallegraeff GM (1993) A review of harmful algal blooms and their apparent global increase. Phycologia 32:79-99

Hallegraeff GM, Lucas IAN (1988) The marine dinoflagellate genus Dinophysis (Dinophyceae): photosynthetic, neritic and non-photosynthetic, oceanic species. Phycologia 27 . $25-42$

Hansen PJ (1991) Dinophysis - a planktonic dinoflagellate genus which can act both as a prey and a predator of a ciliate. Mar Ecol Prog Ser 69:201-204

Jacobson DM, Andersen RA (1994) The discovery of mixotrophy in photosynthetic species of Dinophysis (Dinophyceae): light and electron microscopical observations of food vacuoles in Dinophysis acuminata, $D$. norvegica and two heterotrophic dinophysoid dinoflagellates. Phycologia 33:97-110

Lin S, Carpenter EJ (1995) Growth characteristics of marine phytoplankton determined by cell cycle proteins: the cell cycle of Ethmodiscus rex (Bacillariophyceae) in the southwestern north Atlantic Ocean and Caribbean Sea. J Phycol 31:778-785

Lin S, Chang J, Carpenter EJ (1994) Detection of proliferating cell nuclear antigen analog in four species of marine phytoplankton. J Phycol 30:449-456

Lin S, Chang J, Carpenter EJ (1995) Growth characteristics of phytoplankton determined by cell cycle proteins: PCNA immunostaining of Dunaliella tertiolecta (Chlorophyceae). J Phycol 31:388-395

Lin S, Chang J, Carpenter EJ (1997) Can a non-terminal event of the cell cycle be used for phytoplankton species-specific growth rate estimation? Mar Ecol Prog Ser 151:283-290

MacKenzie L (1992) Does Dinophysis (Dinophyceae) have a sexual life cycle? J Phycol 28:399-406

Maestrini SY, Berland BR, Grzebyk D, Spanò AM (1995) Dinophysis spp. cells concentrated from nature for experimental purposes, using size fractionation and reverse migration. Aquat Microb Ecol 9:177-182

Parpais J, Marie D, Partensky F, Morin P, Vaulot D (1.996) Effect of phosphorus starvation on the cell cycle of the photosynthetic prokaryote Prochlorococcus spp. Mar Ecol Prog Ser 132:265-274

Editorial responsibility: Otto Kinne (Editor), Oldendorf/Luhe, Germany
Partensky F, Vaulot D (1989) Cell size differentiation in the bloom-forming dinoflagellate Gymnodinium cf. nagasakiense. J Phycol 25:741-750

Rivkin RB, Swift E, Biggley WH, Voytek MA (1984) Growth and carbon uptake by natural populations of oceanic Dinoflagellates Pyrocystis noctiluca and Pyrocystis fusiformis. Deep-Sea Res 31:353-367

Sampayo MA de M (1993) Trying to cultivate Dinophysis spp. In: Smayda TJ, Shimizu Y (eds) Toxic phytoplankton blooms in the sea. Elsevier, Amsterdam, p 153-157

Subba Rao DV (1995) Life cycle and reproduction of the dinoflagellate Dinophysis norvegica. Aquat Microb Ecol 9: 199-201

Subba Rao DV, Pan Y, Zitko V, Bugden G, Mackeigan K (1993) Diarrhetic shellfish poisoning (DSP) associated with a subsurface bloom of Dinophysis norvegica in Bedford Basin, eastern Canada. Mar Ecol Prog Ser 97:117-126

Swift E, Durbin EG (1972) The phased division and cytological characteristics of Pyrocystis spp. can be used to estimate doubling times of their populations in the sea. DeepSea Res 19:189-198

Utermöhl H (1.958) Zur Vervollkommnung der quantitativen Phytoplankton Methodik. Mitt Int Verein Theor Angew Limnol 9:1-38

Valderrama JC (1995) Methods of nutrient analyses. In: Hallegraeff GM, Anderson DM, Cembella AD (eds) Manual on harmful marine microalgae. IOC Manuals and Guides, UNESCO 1995, No. 33, p 251-268

Vaulot D (1995) The cell cycle of phytoplankton: coupling cell growth to population growth. In: Joint I (ed) NATO: molecular ecology of aquatic microbes. Springer Verlag, Berlin, p 301-322

Vaulot D, Olson RJ, Merkel S, Chisholm SW (1987) Cell-cycle response to nutrient starvation in two phytoplankton species, Thalassiosira weissflogii and Hymenomonas carterae. Mar Biol 95:625-630

Videau C, Partensky F (1990) Variability in the growth characteristics of Gymnodinium cf. nagasakiense (Dinophyceae) and its consequences for the determination of in situ growth rates. J Exp Mar Biol Ecol 142:169-182

Vrieling EG, Gieskes WWC, Colijn F, Hofstraat JW, Peperzak L, Veenhuis $M$ (1993) Immunochemical identification of toxic marine algae: first results with Prorocentrum micans as a model organism. In: Smayda T.J, Shimizu Y (eds) Toxic phytoplankton blooms in the sea. Elsevier, Amsterdam, p 925-931

Weiler CS, Chisholm SW (1976) Phased cell division in natural populations of marine Dinoflagellates from shipboard cultures. J Exp Mar Biol Ecol 25:239-247

Whiteley AS, Burkill PH, Sleigh MA (1993) Rapid method for cell cycle analysis in a predatory marine dinoflagellate. Cytometry 14:909-915

Yasumoto $T_{1}$ Oshima $Y$, Sugawara W, Fukuyo Y, Oguri $H$, Igarashi T, Fujita N (1980) Identification of Dinophysis fortii as the causative organism of Diarrhetic Shellfish Poisoning. Bull Jpn Soc Sci Fish 46:1405-1406

Submitted: June 16, 1998; Accepted: January 7, 1999

Proofs received from author(s): July 8, 1999 